\title{
MILENA MANOVÁ
}

\section{ČLOVÉK V POHLEDU SOCIOLOGICKE ANTROPOLOGIE}

Sociologická antropologie reaguje na ty problémy, které ostatní sociologické směry $v$ podstatě neřeši nebo záměrně přehližeji. Jde zejména o reflektování a analýzy lidského konáni ve společnosti, čili o svéhybnou veličinu, vytvářející společenskou strukturu, která se může nazývat osobností, integrovanou aktivní jednotkou apod. Hlavní nedostatek, který sociologická antropologie vytýká sociologickému bádání, spočivá $\mathrm{v}$ tom, že se pokouší $\mathrm{v}$ sociálním zachycovat pouze determinačni veličiny, že chce odhalovat pouze zákonitosti společenského dění, že ji takřka nezajímá to, co se nedá měřit (přesto, že některé antropologie samy upadly do tohoto exaktního postupu - viz např. měření typů a jejich vliv na pohyb ve společnosti), a že se tímto systemizovánín vytváři ze společnosti mechanismus, který má svou hybnost kdesi mysticky utajenu a je ochuzen, zbaven toho, co společnost dělá společností - lidské aktivity. Je zbaven poukazu na lidskou činnost. Mohlo by se sice namítnout, že se těmito problémy zabývá sociální psychologie, ale i ta vidí v člověku většinou jakýsi výsledek vnějších sil, člověk se nakonec stává skladbou vyjadřujicí tyto síly a už vůbec se ztrácí jako aktivní tvưrce skutečnosti.

Sledování, jaǩk člověka ovlivňuje společenská skutečnost, samozřejmě nelze hodnotit jako zkoumání, které se snad zabývá něčím neskutečným, nýbrž pouze jako takové, jež v realitě preferuje pouze jednu stránku, nebo dokonce pouze jednu stránku vidí. Neboli není analyzován a nahližen ten proces, jímž člověk realitu tvơ̌í, nýbrž pouze jak tato realita svého tvůrce zpětně ovlivňuje. Podotýkáme ovšem, že sice je nazírána tato sekundární stránka, avšak ne ve smyslu toho, jak vytvořené pưsobí na svého tvưrce, nýbrž jako něco transcendentního. A právě to bychom chtěli vyzvednout jako nejdůležitější poukazy sociologické antropologie. Musíme jim však upřit autorství, nebot tyto poukazy poprvé vyjádřil pro sociologii hodnotným a použitelným způsobem již Karel Marx.

Chceme-li se zabývat problematikou sociologické antropologie, měli bychom si ujasnit nejdřive, ce se vlastně rozumí pod pojmem antropologie. Budeme-li se však pokoušet o jednoznačné zodpovězení této otázky, octneme se $\mathrm{v}$ rozpacích, nebot existuje celá řada nejrůznějšich pojetí od nejširšího, podle kterého je antropologie prostě věda o člověku, až po chápáni antropologie $\mathrm{v}$ ưzkém, speciálním smyslu, majícím na zřeteli člověka a jeho zkoumáni pouze $z$ určitých speciálních hledisek.

Ale i když existuje v současné literatuře mnoho zaměření, i když je předmět antro- 
pologie vymezen velmi nejednotně, v jednom se přece všechna pojetí shoduji: že totiž vědeckým ústřednim tématem je člověk. Člověkem se však zabývají i mnohé jiné vědy, a proto nás ani tolik nepřekvapí, že někteři autoři pokládají antropologii za jeden ze tř́ základních biologických oborů (spolu se zoologií a botanikou), jiní ji nazývají přírodní vědou studující změny lidského organismu $v$ čase a prostoru, a opět podle jiných je to hraniční věda mezi vědami přírodními a vědami společenskými; problémy antropologie se řeši na základě zákonitostí přírodních i společenských. Předmětem antropologie jsou pak vzájemné vztahy mezi biologickou povahou lidí a sociálními procesy.

Podle některých antropologů zaujímá klíčové postavení antropologie tzv. fyzická, zabývající se studiem biologie lidstva. Pưvod a vývoj lidských plemen, stanovení a klasifikace jednotlivých antropologických typů a jejich rozšriření v minulosti i přítomnosti jsou předmětem etnické antropologie. Takzvaná antropogeneze nebo prehistorická antropologie nebo paleoantropologie se zaměřje na studium původu a vývoje lidstva na zemi. Kulturní antropologie studuje existenci a činnost člověka $v$ rủzných geografických a klimatických podmínkách a přimylá se k etnologii a etnografii.

Vývojem člověka a duchovní kultury se zabývá sociální antropologie. Předmětem studia jsou problémy vztahů, společenských organizací, rodinných vztahů, forem sexuálního života, řeši se otázky vnitřní stavby společnosti $\mathrm{v}$ závislosti na biologickém a společenském vývoji člověka. Tím se velmi bliží sociologii a psychologii.

$\mathrm{V}$ novějši době se zavádi pro antropologii označení biologie obyvatelstva. $\left.{ }^{1}\right) \mathrm{V}$ Německu představuje sociální antropologie humánní biologické zaměření výzkumu, zatímco $v$ anglosaské literatuře označuje sociálně antropologickou sociologii př́rodních národů neboli tzv. etnosociologii.

Další nedostatek jasného rozlišení jednotlivých zaměření či disciplín je směšování sociální antropologie s kulturní antropologii. V řadě zemí (mezi nimi ve Velké Británii a USA) je antropologie pěstována jako věda o člověku, jeho kulturním a sociálním vývoji.

V současné literatuře převládá širší výklad a pojetí antropologie. Člověk je v antropologii charakterizován již nejen jako živočich vyrábějící nástroje, ale jako tvor společenský, kulturní, sociální a moxální. Předmětem antropologie se pak stává obecná rovina lidského jednání a lidských vztahů. Člověka však nelze chápat jen jako společenského tvora na různých stupních sociability, ale i jako jednotlivce, který sice pod vlivem společnosti, ale na základě svých biopsychologických zvláštností utváŕi svou psychiku vědomí, svoji osobnost.

Rozhodně nelze vědu o člověku rozpracovat jen na rovině jednotlivých společenských věd, neboť tyto vědy nestačí objasnit problematiku člověka a společnosti. $\mathrm{V}$ systému věd o člověku náleží významné místo filosofii a sociologii. $\mathrm{V}$ každém sociálním systému se vyskytuje problém abstraktního člověka, jeho totality a místa

1) Das Fischer Lexikon-Anthropologie, Frankfurt 1959, str. 296. 
$\checkmark$ přirodě, ale i problémy konkrétniho člověka jako individua i př́slušníka určité skupiny. Člověk ve své složitosti, dynamice a dialektice dějin se postupně humanizuje, seberealizuje a projektuje do budoucna, a tím vytváři svůj zvláštní lidský svět $\checkmark$ kosmu. Člověk není jen jednotlivec, individuum, izolovaný sociopsychický element, ale je předevšim přislušník určité sociální skupiny, třidy, je produktem kultury, je ohraničený mejen svým sociálním prostředím, ale i daným stupněm historického vývoje. Filosofie odhaluje podstatu existence člověka, sociologie mluvi o člověku jako a společenském tvoru vyskytujícím se $\mathrm{v}$ různých rolích, dokreslit jeho obraz složité sociokulturni aktivity ještě reálněji je úkolem sociologické antropologie. Tato disciplína má odhalovat tvář člověka jako tvưrce, aktivního herce svého životního dramatu.

Vznik antropologie se klade do daleké minulosti. Za jejího zakladatele bývá pokládán Aristoteles, nebot ten první užil tohoto názvu. Přesto však, že se antropologie spojuje již s Aristotelovým jménem, je to disciplína stále nehotová. Její vývoj je záležitostí velmi mnohoznačnou. Zdá se, že antropologie $v$ sociologii je vlastně požadavek, nikoliv realita. Je to konstruování hlavně z torz starši filosofie a biologie.

Teorii nebo ideu člověka měla evropská filosofie velmi dlouho společnou s teologií. Bylo to vlastně až v 17 . století, kdy se filosofie emancipovala od teologie. Až do té doby nelze mluvit o filosofické antropologii, otázka člověka se řeší v rámci biologie. Nejde zde o zkušenostní vědu. Člověk ve smyslu teologickém a tak, jak byl viděn ve scholastické filosofii, je výtvor boží. Bůh člověka bezprostředně stvořil tím, že s materiálním tělem spojil duchovní individuální a nesmrtelnou duši.

Descartem se filosofie $v$ 17. století emancipovala od teologického svazku, aniž by byla ateistickou. Ve smyslu přírodních věd interpretovala tělo člověka jako těleso proti jinému tělesu. Přišlo se $\mathrm{k}$ přísnému dualismu: Lidskou duši se zabývala psychologie, jejími formami vyjadřování jazykověda, logika a jiné duchovědy. Toto dualistické schéma bylo mimořádně dlouho živým a použiteiným. V Německu byl tento vývoj přerušen dikky německému idealismu, filosofické epoše, která je spojena se jmény Kant, Fichte, Hegel, Schelling. Nefilosofovali dualisticky, nýbrž spiritualizovali člověka, nebot nechtěli filosofii znovu podřídit teologii.

$\mathrm{V}$ okamžiku, kdy se filosofie počíná osvobozovat od teologie, je třeba otázku: co je člověk? vyjádřit a zodpovědět $\mathrm{v}$ nových kategoriích. To učinil Descartes svou formulí, že „člověk je stroj, ve kterém sídlí nesmrtelný duch“. Tato odpověd se projevila jał̌o aplikovatelná na dualistickou organizaci přírodních věd i duchověd.

Pod názvem filosofické antropologie se představovaly velmi různé a navzájem sotva srovnatelné snahy. Antropologie v pragmatickém pojetí Kanta měla být systematicky nastíněným populárním úvodem $\mathrm{k}$ poznání světa. $\left.{ }^{2}\right)$

Fichtova antropologie je učením o lidské duši. Od psychologie ji však odlišuje

2) A. Gehlen, Studien zur Anthropologie und Soziologie. Zur Systematik der Anthropologie, Darmstadt, 1963, str. 11. 
"ztělesněni duše". Tělo je pojimáno jako reálné vyjádření duše, přičemž duše se jevi zcela metafyzicky jako individuální bytí, jako koneǒná substance.

Tělo je podle Fichta představou vnitřního organického „předobrazu“, ve kterém se vyjadřuje duše. Tato myšlenka se objevuje i u Herdera a znovu ji můžeme nalézt v romantismu až $k$ četným dneš̀ním autorưm. Základem celé školy je teze, že vnější je výrazem vnitřního. Je zde představa těla jako „výrazového pole“ duše. Podle Herdera není člověk ,nechybujícím strojem“ v rukou prírody, ale stává se sám sobě účelem a cílem sebepřetváření. To, že člověk vytváři kulturu, odlišuje ho od každého zviřete a zároveň hu určuje, zdůrazňuje Gehlen. ${ }^{3}$ )

Výchozím bodem je lidské konání. Clověk ve své možnosti existence je odkázán na určitá konání, z nichž nejdủležitější jsou předvídající, plánovité změny věcných obsahů, konáni sloužíi životu, akty a stanoviska vůči jednotlivým předmětům a brzdám, které zasahují až do podnětové sféry. Tam, kde u zviŕete můžeme mluvit o prostředí (Umwelt), je u člověka kulturní sféra. Zviře se cítí $\mathrm{v}$ prostředi jistěji než člověk ve svém obydlí.

Až do poloviny I9. století se teoretický zájem o člověka soustředil na pokusy vyjádřit člověka jako součást světa. Filosoficky je vyvrcholením těchto pokusủ Hegel. $\checkmark$ pohegelovské filosofii se zájem o člověka rozdělil do dvou proudů. Izolované individuum a svět lidských vztahů jsou vysuzovány z pojmu individuality. Reprezentanty pronitho se stávaji Feuerbach a Kirkegaard. Druhý proud, predstavovaný Marxem, přináší ideu zakořenění individua $\mathrm{v}$ procesu společenské práce. Je zde rozvijena myšlenka, jak tento proces tvoři přirozenou základnu $\mathrm{k}$ osvobození člověka. Souběžně se rozviji i obecná orientace na biologii člověka, obecná antropologie a sociologie.

Jedním $z$ moderních směrů je antropologie filosoficḱ́. Tomuto zaměření je odpírán status antropologické disciplíny. Filosofická antropclogie je pokládána za disciplínu filosofickou. Vzhledem ke specifice člověka je nebezpeči extrémủ při řešení této problematiky bud' $z$ hlediska filosofie nebo $z$ hlediska zoologie, jakož i nebezpeči diletantismu, které je způsobeno zvláštním postavením člověka mezi přírodními vědami a vědami o kultuře. Gehlen vysvětluje, že filosofická antropologie se dosud neprosadila jako samostatný a metodicky uvědomělý výzkumný obor proto, že filosofie, zvláště v Německu, se dosud neoddělila od metafyzických tendencí. ${ }^{\text {) }}$ Metafyzická antropologie však nutně končí v ontologických výpovědích, tj. vztahujících se na totalitu světa. Zcela otevřeně metafyzickým a konečně ontologickým způsobem byla ještě pojata podle Gehlena antropologie Maxe Schelera, který patři $\mathrm{k}$ nejvýznamnějším představitelům současné filosofické antropologie. $\left.{ }^{5}\right)$ V r. 1928 se objevila kniha Maxe Schelera Die Stellung des Menschen im Kosmos.

3) A. Gehlen, Studien zur Anthropologie und Soziologie. Zur Systematik der Anthropologie, cit. dílo, str. 22.

4) A. Gehlen, Anthropologische Forschung, Reinbek 1961, str. 141.

5) Max Scheler, Die Stellung des Menschen im Kosmos, München, 1947. 
Clověka neinterpretoval Scheler ve srovnání nebo ve vztahu $\mathrm{k}$ bohu, nỷbrž tím, že se ptal na podstatný rozdil mezi člověkem a zvíretem. Ptal se na rozdíl v podstatě těchto dvou způsobů bytí. A tím byl opět zaveden do otázky po člověku biologický problém. Právě ten problém, který antropologii přenechával obvykle lékařủm a zoologům jako tzv. fyzickou antropologii. Podle Schelera to, co dělá člověka člověkem, není ve srovnání s inteligentními zviřaty ani inteligence, ani představivost, ani pamět, nebot ve všech - v inteligenci, představivosti, paměti, schopnosti volby, $v$ použivání nástrojů spočívá rozdil ve stupni mezi nejvyššími zvíraty a lidmi, ale žádný principiální rozdíl. Zvláštní lidský princip, znamenajíci rozdíl v podstatě, se nazývá duch. Bytost mající ducha není spoutána pudy, nemá stejný vztah $k$ prostředí jako zvíre. Je schopna postavit se do protikladu vůči prostředi, distancovat se od něho. Zdůrazňuje věcnost, vnitřní svobodu, určenost lidského poznání a jednání. Scheler říká: Člověk má svět, má otevřenou sféru věcí kolem sebe, je „weltofen“, i sebe sama může člověk zpředmětnit, má sebevědomí. Je "Neinsager " $\mathrm{k}$ životu $\mathrm{v}$ sobě. Schelerův dualismus nespočíval meżi „tělem" a "duší, nýbrž mezi „duchem" na jedné straně a oduševnělým tělem na druhé. Proti duchu stavěl život.

Zvláštnost postavení člověka $\mathrm{v}$ přirodě spočivá také $\mathrm{v}$ tom, že člověk je fyzicky. nedostatečně vybaven organickými ochrannými prostředky, jistotou, instinkty. Clověk by se svou vrozenou fyzis, se svým nedostatkem instinktu byl neschopen života, kdyby tento nedostatek nebyl kompenzován schopností změnit přírodu tak, aby mu sloužila. Vzpřímená chůze, ruce, jedinečná schopnost učení, plastičnost jeho pohybů, inteligence, věcnost, otevřenost umožni člověku, aby se dovedl pohybovat i v pralese.

Významné místo mezi filosofickými antropology zaujímá také Helmut Plessner, ${ }^{6}$ ) který popsal excentricitu člověka $\mathrm{v}$ odlišení od zviřete a od rostliny. $\mathrm{K}$ filosofické antropologii směřoval Erich Rothacker, jiným představitelem byl Klages, který pojal ducha jako moc vněvitální, životu nebezpečnou. Leopold v. Wiese se zařadil svou prací „Homo sum“ mezi sociologické antropology. Za zakladatele moderní sociální antropologie je pokládán James Frazer. A. Ploetz rozlišuje antropolgickou sociologii a sociální antropologii. Ve shodě s Nietzschem je u něho člověk pojat jako „Neinsager zum Trieb“. Podobně jako Freud zaměřuje pozornost na meurotiky, poukazuje na jejich zvětšený rádius působení a upozorňuje na to, že okrajové neurotizace jsou možné i u normálních lidí př̀i tě̌̌kém situačnim tlaku, a mohou proto býti dūležité sociálně dynamicky, jako masový jev struktury. Vlastní stabilita osobního způsobu bytí člověka má však být $v$ každém případě vioči nim zajištěna. Hildebrand ${ }^{7}$ ) staví pospolitost (Gemeinschaft) výrazně do protikladu k organismu. Gemeinschaft tvoří osoby jako samostatné jednotky. Cásti jsou před celkem, nebot’ osobnost, která se vyskytuje jen jako jednotlivec, má sama vlastní substanciální charakter, sebevědomí

6) O některých představitelích soudobé sociální a filosofické antropologie pojednává $F$. Keiter, Mensch und Gesellschaft, sbornik Handbuch der Soziologie, W. Ziegenfuss, Stuttgart, 1956, str. 247.

7) W. Ziegenfuss, Wesen und Formen Soziologie, cit. sborník, str 247. 
a vnitřní bytí (Innesein), které chybí pospolitostem a které na ně jako celek nepřecházejí. $\mathrm{V}$ analogii prostor - vnějši svět osoby tvoři ve svém styku navzájem interpersonální prostor, který je mezi nimi vlastním médiem. I nenávist probíhá $\mathrm{v}$ médiu interpersonálního prostoru. Jestliže postoje jalko láska nebo nenávist jsou mezi dvěma osobami, pak dochází $\mathrm{k}$ formálnimu nejvyššímu bodu duchovního styku, $\mathrm{k}$ vzájemnému vztahu lásky nebo nenávisti.

Dále můžeme v současné literatuře o člověku pozorovat dvojí proud. Jeden vychází ze studia praktické akce člověka, z jeho chování $v$ závislosti na situaci i na jeho dispozicích. Tento proud sleduje vývoj člověka spíše s vývojem ostatní živé přírody. Zaměřuje se na určité vnější reakce člověka vzhledem $\mathrm{s}$ popudům, které jsou dány. Proti tomuto behaviorálnímu zaměření stojí $\mathrm{v}$ opozici proud antropologický, usilující o podání jisté specifické charakkteristiky člověka a zdưrazňující především jeho odlišnost od živé přirody. Snaži se vystihnout psychické obsahy lidského jednání, životnî pocit člověka, jeho prožitek světa atd. Proklamuje se zásada, že je nutno pojímat lidské jednání jako kličový fenomén. Viktor v. Weizsäcker užil termínu, který se ukázal velmi užitečný: Handlungskreis. Jednání jako klíčové téma člověka. Jednání jako komplexní kruh pohybu. Americkým pragmatistům, jako např. Johnu Deweyovi, patří $v$ tomto ohledu trvalá zásluha, nebot si vzali za základ člověka jako jednající bytost. $\mathrm{V}$ posledni době kniha $\mathrm{H}$. Arendta Vita activa přináši cenné podněty $\mathrm{v}$ tomto směru.

Vlastní potiže filosofické antropologie s empirickou metodou se však projeví teprve tehdy, když se jasně ukáže, že zde musí jít o integrující vědu. Na nový trend integrování věd upozornil W. Schölgen. Jako příklad uvedl sociální vědy, a také zdůraznil, že onen nový typ integrujících věd se ve vědeckých kruzích setkává ještě se zásadní nedůvěrou a odmítáním.

Otázkou integrální antropologie se zabývali i naši antropologové a sociologové. Za předmět integrální antropologie pokládají totalitu obecných problémů věd o člověku. Integrální antropologie nemůže být podle jejich názoru samostatnou vědní disciplínou. Je badatelským oborem pracovníků rưzných věd spolupracujících za společným účelem. ${ }^{8}$ )

V připadu filosofické antropologie má samozřejmě platit, že „modelová“ představa člověka musí být s to zahrnout disciplíny morfologie, fyziologie, psychologie, jazykovědy atd. Pojmy a představy, kterých se u takového modelu člověka používá, musí platit pro „člověka“ specificky a přitom být tak obecné, že jsou použitelné pro stránku fyzickou i psychickou, což platí např. pro pojem jednání. Základní antropologický pojem jako jednání není rozvinut $\mathrm{v}$ žádné jiné vědě. Každá empirická teorie se osvědčuje svou schopností uspořádání skutečností a pojmů a fyziologická antropologie empirická měla ještě být $s$ to povznést se nad schematickou modelovou představu lidí a přinejmenšim integrovat $\mathrm{v}$ sobě základní fenomény sociálních vztahủ, dějiny

8) K. Mácha, Sborník prací k otázkám integrální antropologie, red. Josef Wolf, Praha 1968. 
rozvoje kultury, a měla se rovněž zamyslit nad klíčovým postavením institucí jako manželství, vlastnictví, panství i nad podistatou a pojmem institucí vůbec.

Př́ikladem kulturně sociologické koncepce je teorie kultury Pitirima Sorokina. Předmět kulturní antropologie je podle něho koncepce člověka. Člověk a jeho kultura je základní charakteristika člověka. Smyslem a funkci antropologie fyzické je být bází a východiskem antropologie kultumí.

Filosofická antropologie dosáhla svého vrcholu ve svém hlavním představiteli A. Gehlenovi. Gehlen vychází z německé předválečné sociologie, v núž se odráží vzájemné ovlivňování sociologie a psychologie. Tato tendence byla pro německou sociologii charakteristická stejně jako sociologie kultury, vycházející od Vierkandta, a věda o sociálních interakcích, jejímiž představiteli byli Alfréd Weber a Alexandr von Rüstow. Neméně důležitá byla i sociologie vědění, představovaná původně Mannheimem, později rozvijená T. W. Adornem, N. J. Lieberem, Koblerem aj. Adorno a Max Horkheimer vytvořili obecné teorie společnosti a jejími následovníky byli $H$. Plessner, H. Freyer a $\mathrm{A}$. Gehlen. Ve svém díle věnuje Gehlen pozornost dějinám antropologie, zabývá se problematikou fyzické, sociální a kulturní antropologie, otázkami ras, odcizení, charakterizuje člověka a zaměřuje se na jeho vztah ke svobodě.

Jeho práce Anthropologische Forschung ${ }^{9}$ ) a Zur Geschichte der Anthropologie ${ }^{10}$ ) se snaži vysledovat původ a pojetí antropologie. Pokouší se o rozlišení antropologie fyzické a filosofické, určuje hlavní znaky i vývoj obou. V knize Geschichte der Anthropologie připomíná, že již dávno existovala fyzická antropologie jako doplněk zoologie. Zpočátku je vlastně jednou stránkou zoologie. Studuje lidské tělo. Tato věda byla na počátku pěstována jako nauka o rasách (Rassenkunde). $V$ jejím rámci se rozvijí etnologie. Pozonnost se však zaměřuje na cizí a vzdálené národy. Kant ve svém spise Antropologie mluví o rưzných rasách a národech - je to konglomerát fyzického a etnologického zkoumání. Tento etnologický zájem je tak starý jako západní kultura, poznamenává Gehlen.

Stránka etnologická se spojila se sociologií a anatomií a byla založena Berlínská společnost pro antropologii, etnologii a prehistorii. Pro tuto dobu je charakteristická spolupráce lákařů, národopisců, prehistoriků, statistiků. Tato úzká spolupráce zůstala. zachována ještě dnes v USA. Nastalo však dělení, štěpení, vznikaly nové specializace. Osamostatnila se genetika. Jako jiná samostatná větev se rozvíjelo učení o původu lidstva. Vlastní rasová teorie vyžadovala téměř umělecký pohled na kvalitu tvarů a forem. Jako nová disciplína se vyčlenila sociální antropologie. Zabývala se zkoumáním souvislostí mezi společenskou vrstvou, dědičností a nadáním, dědičnými nemocemi a kriminalitou.

V USA zůstalo většinou zachováno staré spojení etnografie, vědy o kultuře, sta-

9) A. Gehlen, Anthropologische Forschung, cit. práce

10) A. Gehlen, Zur Geschichte der Anthropologie, Anthropologische Forschung, cit. práce, str. 7. 
tistiky a sociologie. Pouze anatomie připadla fakultám. Z tohoto starého konglomerátu se vyvinulo něco, co se nazývá kulturni antropologii. Toto zaměřni dalo možnost využití pro výzkum malých společností, hlavně primitivních, a tzv. prúriodních národů. Američané však poskytuji príklad tohoto kulturně antropologického směru výzkumu i v jeho aplikaci na velký, moderní, vysoce civilizovaný národ.

Protipólem fyzické antropologie je antropologie filosofická, která rovněž navazuje na statši tradice a od poloviny dvacátých let se živě rozvijí různými směry. Existen.ciální filosofický směr se koncentroval tovněž na téma člověka. Dủležitým úkolem filosofické antropologie bylo určení jejîho vztahu $k$ psychologii. Snaži se pojmout obě stránky člověka: duševní i tělesnou. Podstatný rozdíl mezi obrazem člověka minulosti a tím, který se nyní rozviji diky trpèlivé práci mnohých, vidí Gehlen hlavně v tom, že již nevysvětlujeme na člověku bud ducha, nebo pudy, že jsme dostali smysl pro pluralistické $\mathrm{v}$ člověku a zároveň ho vidíme na pozadi daných společenských poměrů. Každé učení o člověku je třeba vidět na pozadí jeho doby. $V$ tom je velký tozdil mezi Freudem a Gehlenem. Antropologický pojem osobnosti můžeme chápat jen $\checkmark$ úzké souvislosti s pojmem institucí, které dávají vlastní kvalitě osoby vývojovou šanci.

Nejznámějším Gehlenovým dílem je Der Monsch, seine Natur und seine Stellung in der Welt. ${ }^{11}$ ) Tato kniha je ukázkou antropologie v jejím moderním pojetí. Antropologii zde definuje jako vědu o člověku ve smyslu přírodovědeckém i sociálním, jako vědu o člověku jako svébytné, zvláštní bytosti, a přitom současně identické $s$ prostředím, ve kterém žije, existuje, působi a tvoři. Takto pojatá antropologie je přirozeným východiskem sociálních věd, uměnovědy i filosofie. Distancuje se od teologického i biologického pojetí, které jsou $\mathrm{v}$ protikladu, od metafyzických koncepcí člověka i od nesprávně pochopené filosofické antropologie. Zaujímá kritické stanovisko $\mathrm{k}$ Schelerovi. Klade si za úkol vytvořit vlastní koncepci, snaži se o postižení problematiky člověka $\mathrm{v}$ protikladu determinismu a svobody. Zdůrazňuje nutnost spolupráce různých specializací a badatelských tendencí, nebot to je nutným předpokladem pro pochopeni člověka $\mathrm{v}$ jeho totalitě, je to hledisko nové antropologie.

Zdá se, že Gehlen chápe sociálni podstatu člověka jako zvláštní způsob jeho přirodního bytí. Důležitou stránkou jeho antropologie zůstává ocenění přirozených stránek lidské bytosti. ${ }^{2}$ ) Na tozdíl od zvírete je člověk bezbranný, bez instinktu, nespecializovaný. Nedostatek instinktivních, vysoce specializovaných orgánů, svět jako neomezená, nekonečně otevřená sféra jeho existence a nutnost žit, to jsou podle slov Gehlena jen rưzné stránky jedné a téže lidské základní siutace. Proto je neobyčejně důležitá schopnost člověka jako učící se bytosti. ${ }^{13}$ ) Může se naučit i těm nejsložitějším pohybům, naučil se desítkám tisíc různých povolání. Chybí mu ale vrozená správnost

11) A. Gehlen, Der Mensch, seine Natur und seine Stellung in der Welt, Athenäum Verlag, Bonn 1950.

12) A. Gehlen, Anthropologische Forschung, cit. práce, str. 33.

13) A. Gehlen, Anthropologische Forschung, cit. práce, str. 10.

80 
instinktivnich pohybů. Zviře však nemá plastičnost a šíri smyslových konání, které člověku nahrazuji chybějící vrozenou jistotu začleněni do skutečnosti. Tyto stránky člověka předpokládaji kulturu, tj. změněnou, zpracovanou, inteligentním konáním nově formovanou přírodu. Sem patři i rodina, manželství, sociální uspořádání.

Všechny lidské společnosti, říká Gehlen, znají celkovou interpretaci světa a vlastni úlohu člověka na tomto světě, která se vztahuje na konání. Podařilo se biologické pojetí znovu spojit $s$ kulturně historickým, aniž bychom museli zavádět dualistické schéma, a tím opět metafyziku. Pojetí člověka jako jednající bytosti pokládá Gehlen za-velmi užitečné a důležité. Nebot se tak klade most mezi biologickým pojetím člověka a pojetím kulturně vědeckým. Žijeme v době, kdy již není problematické panství nad př́rodou. Gehlen vyzvedává lidskou inteligenci, nazývá ji velkou, svobodnou a vǔči všemu otevřenou, je to inteligence, která zná věci, správně soudi, ví, co se stalo, aniž by to všechno zkusila. To je vědění. Existuje vyšší identita svobodného myšlení s událostmi a skutečnostmi a jen úplným oddělením myšlení od života se dosáhne vnitřniho souladu obou. ${ }^{14}$ )

Ve stati „Das Ende der Persönlichkeit“位) si všímá různých pojetí člověka v současnosti i v dávné minulosti právě vzhledem $\mathrm{k}$ lidské aktivitě. Pro antiku je člověk racionální konatel. Podle starokřestanského pojetí je lidské konání slepé, člověk jedná ve tmě, nezná záměry boha, neví, jaký plán bůh sleduje, když jedny státy vytvář́, jiné nechává zanikat, jedny krále povolává, jiné nechává odcházet. Teprve Descartes - jak jsme již výše uvedli - se utkal s teologii. Myšlenka, že člověk je konatel, nezanikla. Stoikové ukazovali, jak proti chaosu stála vždy svoboda jednání.

Jaké je dnešní přesvědčení člověka o sobě samém? Společnost, civilizace, technika, to jsou faktory, které utvářeji člověka v jeho specifickém smyslu. Gehlen ukazuje na jejich vliv a snaži se spravedlivě zvážit dobré i špatné, co přinášejí. Vidí nejen dehumanizační vliv techniky, ale i ten, který identifikuje člověka se světem. Jen částečně lze souhlasit $s$ tvrzením, že masová kultura ohrožuje osobnost, nebot ještě nikdy nebyla tak diferencovaná a vyjádřeníschopná subjektivita. Ještě nikdy nebyli lidé vybaveni tak jemnými anténami, ujištuje Gehlen. Na jedné straně však můžeme hovořit o velké znalesti subtibility individuálního nitra, která vrcholi Nietzschem a Freudem, na druhé straně lze pozorovat uniformování duší. Uniforma se nosí vědomě a právě tak subjektivita. Kriticky se staví Gehlen $\mathrm{k}$ dalšímu znaku moderního světa, $\mathrm{k}$ rutinérství a rutinérům, které pokládá za typické jako osobnosti společnosti orientované zcela na výkon; jiným negativním prvkem je, že všechna veřejnost je pod hypnózou sociálního. Každá instituce, která musí usilovat o moc, podřizuje se diktatuře představ, které máme o sociálním. Jiným nebezpečím je zjednostranění. V žádném případě nemůže být přehlédnuto, že práce stojí v moderním světě na prvním místě. Páteři života je povolání. Je však také profesionální deformace, která, jak se zdá,

14) A. Gehlen, Theorie der Willensfreiheit, Berlin 1933, str. 163.

15) A. Gehlen, Das Ende der Persönlichkeit, Studien zur Anthropologie und Soziologie, cit. práce, str. 329. 
je podle jeho názoru naprosto nevyhnutelná. Se specializací souvisí ztráta osobnosti. Stáváme se sami sobě odcizeni.

Osobnosti hrozi nebezpečí. Gehlen upozorňuje na výrok Hanse Freyera, který zdůraznil, že moderní člověk nežije, ale je žit. Je nesen proudem stoupajici produkce a iluzemi masových sdělovacích prostředkủ. Tento člověk by však měl být jednoho dne probuzen.

Gehlena zajímala otázka svobody člověka. Této problematice věnoval samostatnou práci Theorie der Willensfreiheit. ${ }^{16}$ ) Chápání člověka jako jednajíćího subjektu úżce souvisí s problémem svobody. Proto zkoumání této otázky přikládá Gehlen velkou důležitost.

Nejvyšši svoboda není svoboda morálni, prohlašuje Gehlen. ${ }^{17}$ ) Kdyby se lidé narodili svobodní, neměli by pojem dobra a zla, nebot jednotu svobody a nutnosti; která je splněna $\mathrm{v}$ pravdivém myšlení, $\mathrm{v}$ pravdivém konání, nazýváme tím tvořivým, co je v souladu se sebou samým. Specificky lidskou kvalitou je pochopit sebe sama jako subjekt, ř́ká Gehlen. Clověk není pouze subjektem o sobě a pro sebe, ale naopak, stává se sám pro sebe objektem, a to je podstata jeho racionality. Antropologie, která chce postihnout lidskou podstatu člověka, přicházi tedy $\mathrm{k}$ závěru o dialekticky protikladné jednotě lidského já, což však vyjádřil svým způsobem již Hegel. Dále se zabývá problémem fyzické svobody vưle a moci, vnitřní jednoty rozumu a vůle, poukazuje na dialektický vztah k zákonitosti, řeši vztah svobody a nutnosti. V této práci se objevuje opět aspekt historický, Kantovo a Fichtovo pojetí svobody. Kant a Fichte zkoumaji svobodu ve vztahu $\mathrm{k}$ zákonu a zákonitosti. Zvláště je zde patrné navazováni Gehlena na Fichta. Kantovské a fichtovské pojeti svobody rozvádi ve stati Über die Geburt der Freiheit aus der Entfremdung. ${ }^{18}$ ) Cituje Fichta, který ve svých spisech vypracoval představu, že člověk realizuje svobodu tím, že znovu nabývá vlády nad produkty své samostatnosti, jež se mu vymkly. Od Fichta vede nit $\mathrm{k}$ Marxovi a jeho chápání odcizení, které spočivá $\mathrm{v}$ tom, že vlastní dilla a produkty lidské činnosti a spolupráce se takřka osamostatňují a nabývají převahy a ovládají pak chováni lidí spíš samy ze sebe, než aby byly ovládány lidmi. ${ }^{19}$ ) Gehlen se snaži dokázat, že „materialistické nebo idealistické přestrojeni' je zde lhostejné, že jen na povrchu existuje mezi Fichtovým filosofickým idealismem a materialistickým dynamismem Marxovým protiklad. ${ }^{20}$ )

Pokusme se nyní ujasnit si to záklàdní, to podstatné, oč Gehlenovi v jeho díle jde. Zdá se nám, že když Gehlen podnikal mohutnou výpravu po oceánech filosofie, aby si opatřil základnu pro své vykročeni, ponořil své sítě př́liš hluboko a přiliš široce je

16) A. Gehlen, Theorie der Willensfreiheit, Berlin, 1933

17) A. Gehlen, Theorie der Willensfreiheit, cit práce, str. 163.

18) A. Gehlen, Uber die Geburt der Freiheit aus der Entfremduing, Studien zur Anthropologie und Soziologie, cit práce, str. 232.

19) K. Marx: Ekonomicko-filosofické rukopisy, Praha, 1961.

20) A. Gehlen, Über die Geburt der Freiheit aus der Entfremdung, cit. práce, str. 239 
rozestřel. Tuto skutečnost bychom nepovažovali za zásadně špatnou, naopak, autorovi se ovšem stalo, že to, co se mu podařilo získat, převyšuje jeho systematický habitus. Na Gehlenově myšlení jsou nesporně patrné vlivy Kanta, Fichta, Feuerbacha, Marxe, Freuda, abychom jmenovali alespoň ty nejreprezentativnější, a všichni ho rozněcují a podněcují. Domniváme se však, že Gehlen nedokázal správně odhadnout konselkvence a korelace prací uvedených autorů, postřehnout zásadiní neslučitelnosti mezi nimi, a dává tak mnohé do jedné řady, do řady, $v$ níž se nemohou nacházet. Děje se tak např. u Fichta s Marxem, Hegela s Feuerbachem, Kanta s moderní lékařskou antropologií atd. Gehlen např. řiká, že Feuerbach aplikuje fichtovsko-hegelovské sohéma odcizeni na teologii. Je sice pravda, že schéma si Feuerbach vypůjčil, ale již se zde neřiká, že ve feuerbachovském schématu mnoho chybí a že to, co chybi, není zanedbatelné. Na to velmi správně poukazuje i Marx. Dále ještě považujeme za neúnosnou Gehlenovu domněnku, že protiklady mezi Marxem a Fichtem jsou víceméně povrchovým zdáním. Podle našeho názoru tyto protiklady tkví naopak v samém jádru již z toho prostého důvodu, že světové názory byly pilí̌rem pro jejich teorie odcizení.

Zdá se nám, že Gehlenovým mistrem je více Fichte ně̌ Marx. Tuto domněnku nám potvrzuje zejména jeho práce Theorie der Willensfreiheit, kde se snaži dokázat existenci svobody, nebot bez svobody by člověk nevystupoval jako tvořivá aktivita. $\checkmark$ tomto závažném spise je patrný fichtovský spekulativní přistup při řešení problému svobody a je zde abstrahováno od Marxova řešeni této otázky totální praxí. Tento přistup je pro Gehlena charakteristický i v ostatních spisech. Z reflektovaných autorů vyloupl Gehlen úhelný problém odcizení a opětného vzkřišení člověka překonáním odcizení a ztotožnil se s ním. $V$ tomto problému spočívá podle našeho názoru hlavní těžiště Gehlenova úsilí a zaměření. Z Fichtova odkazu přijímá Gehlen důležitou myšlenku, že podstatou člověka je jeho vlastni pochopení, a dodává, že je tomu tak přesto, že člověk je zároveň dědicem přirodních pudư, u nichž je zřejmé, že právě ony nás zbavují vlády nad sebou a zpưsobují, že jsme domněle svobodni ve svévoli. Marxův vliv je pak patrný na posunu fichtovské problematiky $v$ poukazu na to, že

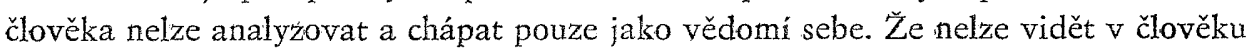
jen pudy, ale že je nutné člověka chápat jako pluralitu na pozadi společenské reality. Neboli ve smyslu lidstva chápat lidství na pozadí jeho výtvorů, to znamená na více či méně odcizené realitě. Člověk pak, vypůjčíme-li si psychologickou terminologii, vystupuje $\mathrm{v}$ úsili autora jako figura. A to by snad bylo možno zobecnit pro antropologii vưbec. Označení figura a pozadí se nám zdaji dosti výstižnými, nebot, jak víme, figura a pozadi si mohou vyměňovat své role, takže pozadí nám mưže být též figurou pro prípad jiného potřebného úhlu pohledu, a dủležité palk je, že je-li společenská realita (např. jakožto instituce) figurou, našemu vnímání zưstává pozadí (člověk) a instituce se nestávaji monstry nikoho. Tento přístup je již jistým krokem k překonání odcizení, dezalienaci, a o to sociologické antropologii podle našeho názoru převážně jde. 